Portland State University

PDXScholar

Women, Gender, and Sexuality Studies Faculty

Publications and Presentations

Women, Gender, and Sexuality Studies

$12-2019$

\title{
Performing Self, Performing Community, Performing Care: A Polyphony
}

Lindsay M. Goldman

Portland State University, glindsay@pdx.edu

Musonda Mwango

Vicki Reitenauer

Portland State University, vicr@pdx.edu

Follow this and additional works at: https://pdxscholar.library.pdx.edu/wgss_fac

Part of the Curriculum and Instruction Commons, and the Curriculum and Social Inquiry Commons

Let us know how access to this document benefits you.

Citation Details

Published as: Goldman, L., Mwango, M., \& Reitenauer, V. (2019). Performing Self, Performing Community, Performing Care: A Polyphony. Feminist Teacher, 28(2-3), 124-140.

This Post-Print is brought to you for free and open access. It has been accepted for inclusion in Women, Gender, and Sexuality Studies Faculty Publications and Presentations by an authorized administrator of PDXScholar. Please contact us if we can make this document more accessible: pdxscholar@pdx.edu. 


\section{Performing Self, Performing Community, Performing Care: A Polyphony LINDSAY GOLDMAN, MUSONDA MWANGO, AND VICKI L. REITENAUER}

We must do everything we can to provide every speaker with the opportunity and the power to participate fully in cultural practices and to critically intervene in them and call into question their normative structure. In short, we need to fight discursive disempowerment with discursive empowerment, silence with speech. -Medina 192

Dominator culture has tried to keep us all afraid, to make us choose safety instead of risk, sameness instead of diversity. Moving through that fear, finding out what connects us, revelling in our differences; this is the process that brings us closer, that gives us a world of shared values, of meaningful community. -hooks, Teaching Community 197

... [P]erformance always entails risk. ..- Hamington 36

This article traces a performative arc across time and distance, starting in the men's carceral setting in which the co-authors ${ }^{1}$ first met in a gender studies course called Writing as Activism; through their continued co-learning (and individual authorship of self) in a campus-based course, Women, Writing, and Memoir; to and through the co-construction of this essay. These coauthors are variously situated relative to the institutions in which they were and are positioned; 
embody difference related to race, ethnicity, gender, class, sexuality, religion, age, and national origin; and are co-committed both to creating learning communities in which a socially just pedagogy might be enacted through performance of self, of community, and of care, and to sharing about that experience as if, in the words of José Medina, "from elsewhere."

\section{Starting "From Elsewhere"}

Our work together started in a place that is designed and constructed to be quite "elsewhere": the state correctional institution in which Writing as Activism (originally designed by co-author Vicki Reitenauer as a campus-based course and offered since 2016 within carceral facilities as an Inside-Out course ${ }^{2}$ ) took place. Twice a week, for the eleven weeks of spring term 2017, twelve Portland State students, including co-author Lindsay Goldman, processed into a state minimumsecurity correctional facility where co-author Musonda Mwango and eleven other incarcerated men waited in Classroom 4. In this practice- and process-oriented class, all of those in the room (including the instructor) contributed to the constructing of course content and the facilitation of class time. These shared content-and-process responsibilities included selecting readings for inclusion in weekly reading packets; co-designing and co-facilitating class activities, including weekly writing workshops; and serving as writing coaches and sources of constructive critique. Each participant began the term generating a critical self-reflection in which they adopted learning and writing goals and identified one or more explicit writing projects they were taking on for the term. At term's end, participants revisited their learning and writing goals in critical self-reflection, which included their claiming of their grade for their efforts in the course. ${ }^{3}$

During the weeks that we met, related, and learned together across institutional lines, we 
unwittingly began the collaboration that led to this essay. As we again worked together in the learning community formed in the campus-based course Women, Writing, and Memoir (which Musonda registered for following his release), we found ourselves drawing directly on the knowledge we had co-produced through our earlier course as we became actors in a new setting. We engaged in conversation together to make sense of our new experiences in light of our former ones, interrogating the meaning of our individual and collective practices in the forging of new ways of being as learners, writers, and collaborators. Having started from the "elsewhere" of a state prison — and under the guise of individual selves sitting in a circle in a classroom in that space - we have traveled, together and alone, to a sense-making place, a place for wondering how we might continue to engage in performative liberatory change-making practice through claiming our selves, welcoming others, and forging bonds of genuine care.

\section{Co-Creating Our Feminist Classroom}

This inquiry into the meaning of our practice(s) leads us to claim that radical possibility in feminist classrooms emerges from the performance of three expressions - that of a self, acting as an agent of their own experience as a necessary part of the whole; that of community, which explicitly invites and expects the whole-person participation of each member of the group; and that of care, in which the members choose to make and sustain connection and intimacy across difference, in particular (in our case) outside of economic arrangements that demand the performance of care.

At the heart of our engagement together as co-learners and co-teachers, we recognize ourselves as performers: of selves making our stories known both reflexively (that is, to ourselves) and interpersonally (to the others who have constituted our learning communities) 
through both writing and speech; of community, through intentional relational engagement with others, including our adoption of a shared commitment to co-design course content and cofacilitate pedagogical processes; and of care, through engaging with others in ways intended to contribute to mutual well-being. Through this collaborative writing, we seek to further that recognition by performing this work on the page.

While we claim here that new ways of being, of being known, of knowing others, of making and doing, and of (co-)creating knowledge(s) are possible within the feminist classroom precisely because of the dynamic, practiced relationships among self and community grounded in the nonmaterial giving and receiving of care, we simultaneously understand that our situation, our learning contexts, are particular. What follows is not a blueprint. We hope, instead, that this critical reflection on our individual and shared practices will, first, be enjoyed as text, as you, the reader, perform your role in listening for both what we say and what we don't say, can't say, or don't know how, yet, to say. Further, we hope to catalyze your wondering about how, in the feminist learning spaces in which you operate, you have performed self, performed community, and performed care - and how you might, within your particular context, hone and deepen those performances.

In telling this story of how we individually and collectively came to "perform self, perform community, and perform care," we have chosen to disrupt the traditional article paradigm to create an essay that employs an intentional polyphony (Medina) and polyvocality (Ghorashi) that are themselves reflective of the strategies we employed in the power-sharing learning environments we built and occupied together. To that end, we first met to discuss this article and to choose an approach to writing it that echoed our embodied engagement. We decided in that first explicit conversation to braid our individual stories throughout this piece 
with feminist and queer practice and theorizing that especially resonated with us.

As we self-consciously began to shape our discussion into this article, we engaged in a real-time polyphony to reflect on what we were making, wonder at our perspectives on the text, and imagine what performance of this sort makes possible. This evolving conversation itself was both performed and constructed, taking place both informally and formally (that is, with the intention of moving this project forward), often over a shared meal. The conversation included individually generated reflective writing on our experiences and culminated in a real-time generative session in which we collaboratively "spoke" with each other through a collective Google document.

Our polyphony, then, reflects a methodological syncretism, as we acted out and then built towards the text you now read. What follows here is first our idiosyncratic review of the literature that grounded and animated our investigation into the meaning of our experiences. After that, we invite you directly into our polyphony, the heart of our selves making community through the performance of care, which continues to weave the language and literature that we drew on for grounding and inspiration.

\section{The Language and the Literature}

This collaboration began with our work together in two feminist classrooms and extended beyond the formal classroom into informal co-learning spaces, which came to include our explicit investigation into our experiences as performers of self, choosing to engage individually in a collective performance of community through the enacting of care. As we interrogated our experiences, we turned to literature that illuminated elements of our experiences and used this literature to provide a foundation for this polyphonic sharing. 
We each entered Classroom 4 inside the minimum-security prison in northeast Portland profoundly unsure of the experience that awaited us. We had our selves - understood by us to mean the totality of our individual personhood that 1) is intersectional relative to our multiple identities, 2) bears the intersecting forces waged against us, and 3) is capable of expressing agency relative to those identities and those forces (see, for example, Willett et al. on various feminist perspectives on the "self")—but how those selves would relate to each other, how they would come to impact the experiences of the other selves in the room, remained uncertain and would only be revealed through the actions we would individually and collectively take.

Many of our differences were obvious, and we'll identify a number of those differences in the trialogue to follow. If we were to become "community" in the sense expressed by psychologist and education scholar Candyce Reynolds - that "a community is a place where, if a person is missing, that person is missed"-we would be required to forge connection across these individual selves positioned variously around the literal circle into which our tables and chairs were arranged and within the institutions from which we came.

In that first class session inside the prison, dressed as we were (in blue prison denim for the incarcerated students, and in loose-fitting clothing that was anything but blue denim for those from the outside) and positioned as we were, alone with our individual selves and lives and stories about our lives, we began by writing. We engaged from the very start as creators of narrative and as performers of those narratives with and for each other. Anthropologist Halleh Ghorashi speaks to the power of constructing and sharing narratives within her own polyphonic project: "Choosing this particular form [polyphony] meant creating space for sharing and constructing the narratives in a relational manner. Polyphonic writing not only unsettles the fixed boundaries of normalized categorizations, but also disrupts the fixed boundaries of power in 
terms of authorship. If polyphony demands relationship and difference . . . then the textual polyphonic production provides alternative voices in relation to dominant discourses through dialogical agency" (60).

In Ghorashi's view, crafting and sharing individual narratives encourages others to reencounter and reconsider their own stories (and thus, importantly, their own selves), to recognize experiences they may not have lived, and to catalyze the expansion of the stories of the one(s) who have lived those experiences. Doing so helps us broaden the persistent habits of thought that confine certain individuals to a threatening "other" while recentering the focus away from the previously dominant narrative. "Providing space for multiple voices to engage with one's self narrative led to co-production. In this way, self narratives were negotiated by the voices of others, which enabled relational, dialogical narratives of the self" (63). In this way, every voice in the room may be heard; every story, valued.

Ghorashi names how, in order for any project of this nature to occur, there must exist spaces that allow for a disruption of the forces that discourage it: "The main condition for this space is that it should be safe, and safety is provided when the space is as empty as possible from judgments. People would be able to share their stories in freedom if they felt that they were not judged because of their background or the choices they made . . This marginal safe space enables narratives to come together from positions of difference in order to negotiate discursive positioning, constructions of shared meanings, and the production of counter narratives to the dominant discourses of hierarchical categorizations" (61). These words resonated for us in our discussions, aligned with our experiences of negotiating difference through the collective performing of our own self-narratives. We wondered how, exactly, we began to traverse these differences, to risk vulnerability, to dare to build a space that Ghorashi identifies as "marginally" 
safe, when the fact of the environment in which we were meeting itself existed by way of the literal (legal) "judgments" that had put half our class there. In other words, how could we overcome the weight of judgments on which the whole prison system is founded? Not that "judgment" would be missing from the other formal space we would occupy together in a campus-based course, either; but judgment seemed acutely present in the prison classroom. How, then, might a group of individual selves choose to perform together in ways that approach the liberatory possibilities Ghorashi identifies above?

We simply began, we decided, in the places where we found ourselves - the three of us as we authored this essay, and the three of us learning with our comrades around the circle. Our beginning may have started in a starkly lit classroom inside a prison. But our work together didn't stop there, or with the second classroom space, this one within a university campus. bell hooks tells us that "education as the practice of freedom" can happen anywhere, that it is not confined to a classroom setting, but occurs wherever people convene to share ideas (such as in the collaborative writing of an article, say, or in the meeting of author and audience as that article is read) (hooks, Teaching Community). hooks believes that this community in which liberatory learning happens is committed to connection, to care, to love, while cautioning us that, "[ $[\mathrm{t}] \mathrm{o}$ speak of love in relation to teaching is already to engage a dialogue that is taboo" (Teaching Community, 127). If we can move past the initial discomfort of the term love in an academic setting, then we may allow ourselves to follow its guiding principles of the giving and receiving of compassionate understanding. This dedication to connect meaningfully to one another allowed us to move beyond an externally derived standard of objectivity while enjoying a rigor born of shared struggle. "Embedded in the notion of objectivity is the assumption that the more we stand at a distance from something the more we look at it with a neutral view ... [Teachers] may 
choose to think of students as empty vessels into which they are pouring knowledge, vessels without opinions, thoughts, personal problems, and so forth. Denying the emotional presence and wholeness of students may help professors who are unable to connect focus more on the tasks of sharing information, facts, data, their interpretations, with no regard for listening to and hearing from students. It makes the classroom a setting where optimal learning cannot and will not occur" (hooks, Teaching Community 129)

In hooks's view of a vibrant, liberatory community of learners, instructors do not perceive students as vessels waiting to be filled with information to then regurgitate on an exam, but rather as active agents, active performers, of the production of knowledge- and they encourage and even perhaps require students to perform in ways that suggest they perceive their co-learners as agents, too. For hooks, the liberatory potential of such engagement makes our every learning context a "location of possibility": "The classroom, with all its limitations, remains a location of possibility. In that field of possibility we have the opportunity to labor for freedom, to demand of ourselves and our comrades, an openness of mind and heart that allows us to face reality even as we collectively imagine ways to move beyond boundaries, to transgress. This is education as the practice of freedom" (hooks Teaching to Transgress, 207). Further, the enactment of this sort of reciprocal recognition, regard, and encouragement is a practice of love, as it invokes the spirit of partnership in the learning proposition, and vice versa: "All meaningful love relations empower each person engaged in the mutual practice of partnership" (hooks Teaching Community, 136). The formation of a community of co-learners, then, requires a collection of individuals to engage in a mutual practice marked by loving relationship forged across the very real differences at play.

If engagement in feminist classrooms involves the assertion of self in generative 
relationship with others in community, what connects these two performative modes? What serves as the switch that allows individual persons, who arrive in bodies filled with the residue of generational trauma and their own lived experiences and, perhaps, with the hope that this classroom space might be different than others that have been survived, to understand themselves as part of something more, something bigger, something beyond? What generates possibility for the kinds of changes in awareness of self, others, and the world that constitute liberatory learning?

According to feminist care ethicist Maurice Hamington, it's the performance of care. Defined as "a constrained choice of an action to be performed and effectively received" (34), caring acts "are physical performances that may be witnessed by others but are always witnessed by myself. The unique human capacity to be both subject and object makes it possible to experience moving and interacting with others from this dual perspective. The physicality of caring performance adds to the instantiation of identity. Similarly, caring performances entail knowledge production. Every choice to engage in caring actions is an opportunity to learn more ..." (35). In the classroom that Hamington examines in his article, students collaborated to understand and produce knowledge around care ethics through formal performative exercises that served as practice sites for caring action. Hamington asserts that these intentionally chosen modes of operating — these caring performances—-have "an epistemological dimension ... $[C]$ are and knowledge production are in an interlocking dance. The more I know about someone, the more it opens up the potential for care. As someone becomes more concrete to me, they become less of an 'other,' allowing me to find commonalities and connections" (32-33).

While "care" in its larger context is certainly both complex and complicatedparticularly as it interacts within financial arrangements that reinforce the marginalization and 
precarity of those relegated to "care work," "this narrower perspective on care within teaching and learning environments focuses on "caring" as a mode of being that can be enacted by agents within those environments and built upon for the purposes of collaborative knowledge production. In the constrained environment of the minimum-security correctional facility in which we first knew each other and in the also-constrained environment of a university classroom, we chose, over and over again, to build, nurture, and test bonds of connection. We practiced writing and telling stories as individual selves electing to engage in a community in which persons who were missing were missed. We examined our assumptions and biases in close proximity to others who embodied and reflected difference. Sometimes we resisted change; sometimes we embraced it. Even as we grappled with our own internal conflicts, we worked deliberately and consciously to resist the dehumanization that characterizes discursive and material relations in places like prisons and universities.

Here, we believe, Ghorashi, hooks, and Hamington meet in a theoretical space that mirrors the spaces we have inhabited together — spaces to which we've brought our whole selves as actors, thinkers, and feelers. We might have chosen many different ways of acting towards ourselves and each other, varying modes of performing ourselves within the community of our learning environments. We chose to enact care. A constrained choice within constrained environments, it opened doors of possibility for new ways of being individually and in relationship with others_-including as co-authors of the polyphony that follows.

\section{A Polyphony}

Vicki: Good morning you two! Here we are, meeting on the page to say something about our ideas that feminist classrooms, as places of possibility on the individual and collective level, are 
sites where the performance of self becomes the performance of community through the performance of care in relationship across difference. Where should we start?

Musonda: I'm thinking about the first time that we all met. Vicki, you were an assistant professor at PSU with a passion for social justice activism and championing education in correctional facilities, and Lindsay, you were a junior at PSU pursuing a degree in liberal studies with a desire to understand the prison industrial complex. I was an inmate serving time for driving under the influence. From the moment of our first encounter, a power dynamic had been established — at least in my mind. I was dressed in prison garb, while you two were dressed in fashionable street clothes. I had been incarcerated for almost a year, so I thought I had at least gone through the stages of grief to help process the predicament I had found myself in. I was, though, securely bound in a cocoon of self-doubt and low self-esteem. And even though I had attended college prior to my incarceration, the prison environment had served to erode any sense of confidence I had about my ability to succeed or hope for regard in academia. I felt dumb! Lindsay: And I felt objectified - though not necessarily because of the actions of the individual men waiting for us in Classroom 4. The outside students, including me, all happened to identify as cis and trans women. We had been instructed on specific clothes to wear, and more specifically what not to wear: nothing too tight, nothing too revealing, no blue jeans, no navy, no denim, no hats, no underwire bras that might trip the metal detectors. We had all carefully selected our outfits in an attempt to adhere to the clothing restrictions never required of any other class - though as women, consciousness of dress is not a new phenomenon. The whole process of entering the facility felt alienating to me. I remember it distinctly: We met in the parking lot of the facility and then followed you, Vicki, to the set of double doors that marked the entrance to the facility perimeters. You pressed a button and said We are here for the Inside-Out class. A 
loud buzzer unlocked the first door. We all walked through, closed it behind us, and huddled together until the second buzzer opened the door to release us into the prison courtyard. We went up to the first security checkpoint and placed our government-issued IDs in a bin to be marked off one by one. We were each given a badge in exchange. We walked as a group to an adjacent room with a metal detector. We removed keys and phones and jackets and placed them in a locker to be retrieved after class. We took turns using the restroom, knowing that once inside, we would not be permitted to leave without a guard. One by one, we walked through the metal detector, waiting to be cleared. We flipped through our notebooks to prove nothing was hidden inside. Once everyone had completed each step, we entered the facility, each signing our name into the visitor log. After the last person finished, we walked across the hall to our classroom, a bare room with whiteboards on one side and windows facing the hallway on the other. The "inside" students, men dressed in denim, had already seated themselves around the circle of desks, at least one seat apart. We knew to fill the remaining spaces in between. I was immediately overwhelmed with the feeling of being an object, my gender undeniable, my consciousness of it palpable. My internal dialogue was rampant with assumptions and questions and fears and self-protections; these thoughts were loud inside my head. We took our seats, exchanged handshakes, and the piercingly quiet room began to fill with introductions, as we traded first names (or chosen names) and small talk, the pressures of maintaining conversation finally giving my mind an alternate focus.

Vicki: I have strong memories of our first night together, too. In every moment of that night, I felt myself performing as the person with the badge — in this case, the volunteer badge that lets me into the facility and allows me to be responsible for the outside students I bring with me. At the same time, I fundamentally believe that being the person vested as the authority in the room 
(whether that's a classroom in a correctional facility or one in a university building) requires me, if I am to operate in a way that promotes liberatory learning, not only to interrogate my claim on power, but to work deliberately and actively to redistribute it. That's a challenging proposition in the hyper-regulated space of a prison, and in the also-regulated space of a university.

So there I was, the instructor, a white, cis, queer, working-class-reared woman interested in "education as the practice of freedom," (Freire; hooks Teaching to Transgress), having, for example, to practice being hyper-aware of what everybody's wearing, in order to advise proactively on wardrobe changes that may help us get into the institution with a minimum of pushback from the security staff. For me, this is the fraught nature of the performance of self, community, and care in this context: Noticing what people wear and commenting on it, suggesting its modification. Forging connection with those with power that far outstrips mine. Appearing to have it all under control as a modeling of discipline and strength for those who have less power than I do, those who are counting on me to grease this particular wheel, to exit one world - that of those of us who are not incarcerated - and to enter the world of those who are.

Once it's just us inside Classroom 4, I finally let my guard down, feeling the strain of the performance relax a bit, if not the performance itself. There was still that first class to facilitate! We were still new in our shared performance of community, our developing network of care, so I had to stay focused on playing my part as well as I could, even under those fluorescent lights that give me a headache every time.

\section{What else do you each recall from our first sessions together?}

Lindsay: We began each class with a check-in question prompted by one of the students, and 
took turns giving our answers and listening to others give theirs. This routine is so simple, but it sets the groundwork for our engagement to follow. From day one, we began to create a space that is as much about sharing as it is knowing when to listen — an invitation to learn a little more about one another. You may pass if you want, and one or two people generally did, though not the same persons all the time. But there was a sense from the beginning that we had all chosen to be here, and we continued to choose how we wanted to be present - that is, we performed self as we came to know each other in seemingly low-stakes ways. I still vividly remember details from those go-arounds: favorite books we have in common, formative pieces of advice we have received, animals we wish we could be, who would rather lose their elbows or their knees if forced to live without one or the other. We laughed together. We shared. We sometimes forgot where we were - at least I did.

Musonda: The first few class sessions were unnerving for me. Although you did not facilitate a pronoun check in this class ${ }^{5}$, in several small groups some of the outside students insisted on sharing pronoun preferences. From the jump, this stood out to me especially, as I am a cisgender African immigrant from a conservative background who had never known of a setting where people could choose their pronouns. This went on in the various small groups I was a part of until about the third class, when we finally seemed to focus more just on the writing and put all the social constructs aside. I love writing, so as soon as we began to do this I felt we were on a level playing field. My prison garb, my crime, my environment did not matter anymore. This was now all between me, my pen, and my paper.

Vicki: That's really interesting, Musonda. What I hear you saying is that focusing on your writing, on telling whatever story it was that you were putting on paper in whatever way, allowed you a freedom to be who you are, apart from the social regulation that is present in any group 
we're operating in and the way that regulation does and does not play out. And, further, that that put everyone on a level playing field—or at least you felt that way.

Musonda: That was definitely true for me. Although I'm generally chipper and positive in demeanor, I struggled with how to navigate the relationship dynamic that I had formulated in my mind in the early days of our class. From the outset you told us that your goal was to create a space where students from both outside and inside could exchange ideas and then transfer those ideas into writing. But despite your making that very clear, it was still hard for me to relate to you or the outside students on an organic level, primarily because of the environment I was in and the perceptions I assumed they had of me and the other inmates. Another hurdle was of course wrestling with the "new" ideas of gender and sexual identity evident in our class but that are massive sticking points in a prison environment largely driven by a particularly blunt misogynistic masculinity. For me at least, there was the fear of thinking that, if I embrace the different identities of people in our class, word would get out to the prison yard and somehow make me a target who did not subscribe to the prison culture.

But as the class unfolded and we were encouraged to share our writings with each other, I really came into my own and started performing "in my own skin." The thread that was woven throughout all our writings underlined our common humanity and challenged our prejudices and changed perceptions of each other. Though I had been baffled and unsure of what to think of my colleagues, including cisgender and transgender women and those who rejected the gender binary, all of a sudden their confidence, though veiled in vulnerability, helped me develop an affinity for their way of thinking. And in so doing I felt empowered to be myself even more. I am an African immigrant (with an accent) and have sometimes felt uncomfortable (especially in today's America) about sharing my story. This environment stripped that uncomfortable feeling 
and allowed me to start writing my memoir, especially since written words have no accents. Suddenly my story was not a point of shame. I began valuing my story and found ways to articulate it in a manner that highlighted the poignant and pensive moments as well as the celebratory and endearing moments. Our classes together became an exercise in embracing selfvaluation, especially after my having gone through some deep personal turmoil over the past few years. Over the course of those eleven weeks, I got to know my colleagues so well I extended myself even more by sharing some of my music with the class, as I am currently a musician by trade.

Lindsay: As part of the course, we were each responsible for leading the class in a writing workshop. We worked in groups to design and share the leaderships roles of our facilitation. Unlike most other classes, however, we did not have the privilege to exchange numbers or emails or meet for coffee to finish our work. We only had the time allotted, so we knew to use it well.

Productivity became an act of respect. The same is true of our writing feedback groups, which we had also self-selected. We brought multiple copies of our pieces for each member to read. We asked specific questions tailored to the author and gave suggestions as to how to best promote their story, not our version of the same.

In these simple assignments and activities, we each had and used the power to commit to one another, to hold space for one another, and to allow each individual to choose how to use it. In this room, the way we conducted ourselves was clearly a choice — a gift that seldom seems to exist in other classes and was additionally heightened by the surrounding environment determined to strip and inhibit one's autonomy and agency. But prison isn't the only environment that does that $—$ so do universities, among so many other places. Like bell hooks 
helps us see, we are always in a feminist classroom, if we choose to perceive things that way.

So for a few hours twice a week, because of how we intentionally chose to perform, we began to exist outside the institutions, outside the correctional facility itself and its resolve to dehumanize, and outside the realm of academia that too often discounts certain forms of knowledge. We did not all pretend to be the same, and we did not attempt to shield our differences so they would be more palatable. As Ghorashi talks about, we embraced the facets of our narratives that make us distinct and that connect us. We wrote about them and offered them boundless permission to be.

Vicki: Your thoughts here bring to mind Hamington's idea about our performances being things that others witness but also things that we witness within ourselves - that is, we are both subject and object, performing and experiencing/witnessing our own performing. How do you think this has played out for you in terms of your self-identity, your sense of community, your sense of bringing care into the settings in which you operate? In other words, how have your self-concept and how you operate changed because you have witnessed yourself performing in certain ways? Musonda: There definitely is a performative aspect attached to creating community, because while many times there are organic components at play that bring people together, e.g., shared interests, values, and goals, the viability of our community came from our conscious and deliberate actions. And performance means consciousness, and sometimes self-consciousness. This, of course, is the place we were functioning from in our first meeting, especially with guards looking over our shoulders to make sure we followed every regulation and that there was no appearance of impropriety. Anyway, my point is there was a conscious awakening around what we did. Like I mentioned earlier, part of my zeal for school today came from the classroom experience of that Inside-Out course. We were so conscious of each other's feelings and 
opinions. So continuing community for me means carrying the tenets that we fostered in that environment past the time the physical experience ended. Of course this is hard, because in other classroom environments, not everyone will come with that ethos.

Lindsay: As for me, anytime I think of performativity, I think of Judith Butler on gender performativity and, by extension, performance around sexuality. I really love the question how have your self-concept and how you operate changed because you have witnessed yourself performing? For me, the first thought that comes up is a performance of sexuality, that in nearly every room I am assumed to be straight and then, depending on the circumstances, figure out how to make known that that isn't the case, almost like an apology, because then others feel uncomfortable for guessing wrong. I remember specific moments in the correctional facility when I was very conscious of wondering whether or not that was something I should share, which made me more aware whenever anyone else announced themselves as representing a nondominant identity.

Vicki: I've got so many thoughts going on from what you each have written. To start, I'm wondering about how important listening is, and attunement to others — how being and operating in community, performing community, requires us to listen deeply both to others and to our own inner voices - and not only to what's being said, but to what's not being said. Listening to and paying attention to the silences as well as what is spoken out—which Medina talks about in Speaking from Elsewhere. The educator Parker Palmer quotes feminist theologian and racial justice activist Nelle Morton about how we must "hear people into speech"—and both of your responses here evoke that for me. It's interesting how this process reflects that in-person reality, in that we're each in our own physical spaces, writing this in real time but across distance, "hearing each other into speech." We're attuned to what each other is writing - and even 
possibly watching each letter, and then each word, and then each sentence, come into view (with some letters and words and sentences being erased as we start over). Performing individually and collectively on this "page," and watching that performance unfold as members of each other's audience even while we're writing “actors," too.

Lindsay: I was just thinking the exact same thing about the performative aspects of this "session," for lack of a better term, and what our individual internal dialogues are saying about what voice we need to write in or how academic we should sound, since I'm sure our writing here would differ from a standard message/text to a friend - but then again, maybe not.

And Vicki, I agree that community isn't possible without listening, both to what is said as well as the silences around them. I love that idea of "hearing each other into speech." I think about the dynamics of our writing groups, and how it seemed (at least in my group) that we were all equally aware of how much we had shared/spoken in comparison to our other members, so that we would explicitly each encourage those who hadn't yet shared and get quiet when it felt like we had been speaking for too long. Perhaps that's a way to directly be listening for those silences, and then encouraging ourselves and our peers to break them when desired.

Musonda: Let me add to what you said about listening for silences. Inside scoop, most inmates sign up for a class such as the one we had for various reasons, but one of those is simply outside contact. Contact with people who are not inmates, sometimes with the hope for maybe something more personal. So when you are told you will not be able to maintain a relationship after the class ends, it is very disheartening. At some point it became fairly apparent, both because of the rule about post-course contact and because of folks' sexual identities, that the outside students were just not going to be available for intimate relationships. At that point it opened the door for listening for silence, in a sense. This seems to me to be a continuation of what I said about being 
deliberate. Once that possibility had been dispelled and hopes dashed, it really became way more academic and more real, at the same time. People from my side were listening more to what was being said by a person, rather than seeing them as a potential intimate partner. I do not know why I am mentioning this, but maybe just to give context to the complexities that accompany creating a community in an environment like that.

Vicki: I think that really shows how complex any particular context is, with everyone coming to it with their own motivations - both understood and not completely understood, even to the person holding them. There's something really moving to me that inside students who perhaps originally chose to come for one particular reason might stay for a different one - might find something there for them, even if it wasn't what they thought they were looking for. Each of us is so profoundly complex, and we come together from those complexities - and then we manage actually to care about each other and build something together and take something meaningful out of it? That's amazing.

Musonda: Lindsay, I have a question about your thoughts on performing and disclosing sexuality. I'm thinking the performance of sexuality is a performance of self. Do you feel that disclosure enhances the performance of community?

Lindsay: Hmm. That's an interesting question. I think it's really about sharing, and how, when we're actively and intentionally performing care with one another, we grow closer when we share. Often community is created out of vulnerability—not to the point where that is a demand or expectation, but rather an invitation to share with other people when and what you want to. Just like with our friends/family/anyone we're close to, we share certain things about us to know one another better. For me, being queer is a huge part of my identity, and I want to be authentic about that. There were multiple times when someone asked about a boyfriend or something, 
implying I was straight because that's the typical assumption, and at that point, correcting them became a way of expressing my authentic self, which I think adds to that sense of community, when you can share something else about yourself with others. But by no means do I think there should be expected or required levels of vulnerability at the start of any community space. Such a requirement, I suspect, would work against the establishing of community.

Musonda: I have an almost similar situation in the sense that in most circles I go in, I make it very clear that I am an immigrant and, more recently, a very proud immigrant. Partially I think I do it as a way to be excused if I might not have any knowledge of the cartoon everyone is laughing about. But I have noticed that in some circles that immediately denotes me as "other." The performance of self, meaning my living proud and free in my heritage, actually creates a certain uneasiness in the way that people behave. So in a way I almost kill the energy. Of course you are right, that this does not come at the beginning of a gathering or in the early stages of community building, but at times I have found that it is very hard to decide when to share what. Maybe when you wait too long, there might be things said that are offensive because people thought you were something else, and if you disclose certain elements of identity too early, others shut down immediately. It is such a fine line to walk.

I will give you an example. My accent is fairly subtle, and when I want to I can go total American. I have had instances when I've hung out with some Black Americans that had a disdain for Africans, and they would say some things, assuming I was a Black American as well. And then they find out I am not, but it is too late. You get what I am saying? In the same vein, I think to myself: had I started with telling them I was from Africa, would I have even made their acquaintance? So I was just wondering how maybe you have performed self at the cost of community or vice versa? 
Lindsay: I'm curious what you mean by "too late" in revealing your heritage. I think this at some point comes into question for anyone with one or more marginal identities, this decision of whether or not to reveal yourself, whether for safety reasons or fear of rejection or whatever it may be. There are definitely times when I have been in similar situations, where I am assumed as one thing and then announce myself as something else to the point of making others in that company uncomfortable. But I do not want to ever feel the need to apologize for being myself. And if that is the expectation with the group I'm in, if others are uncomfortable or disapproving of a formative aspect of my identity, then I don't care to associate myself with them. So in that case, perhaps you could say that my "performance of self" has potentially cost me community, but at the same time, any community space where we are forced to hide or apologize for parts of ourselves, doesn't seem like community to me, though that is perhaps a privileged position to take.

Musonda: At the same time, in the context of our Inside-Out class, even though there were elements of our identities we revealed slowly, we managed to forge bonds because we focused our energies not on the performance of self in the sense of "identity" but on performing ourselves in sharing our narratives as a key component of performing community. This, for me, is also partially cultural, because the collective in my culture supersedes the individual every time. I think the performance of self is important and integral to everyone's progress and development, but at the same time, or at least in my view, it should not come at the cost of community. Now this is not to suggest that you and I cannot live in the reality of our individual truths, but that in every context it is important to gauge the situation so as to know what our common objective is and explore how our performances of self will enhance the community.

Vicki: I think you have both named this productive, generative tension between self and 
community beautifully here. It seems to me we're always toggling between asserting ourselves as individuals and operating relative to groups, including sometimes suppressing information about ourselves for one reason or another within the group — in order to protect ourselves, or to generate a feeling of belonging, or to not rock the boat, or simply to be liked. That's a constant negotiation for individuals in association with others—and, actually, a negotiation that has to happen internally, first, as we choose what and how to disclose who we are and how we have been shaped — and how we go about doing that disclosing (and when we feel it's necessary) has everything to do with our complex intersectional identities within spaces marked by intersecting forces of dominance and submission.

I wonder if a major factor in how well we negotiate this self/community balance is, in fact, care: self-care, where we recognize our needs both for self-protection and for being seen and known in the ways we choose to be known (if such a choice is available to us), and care within the class community, such that there's an elasticity in our relating that can absorb the revelations that we might choose to make only after those bonds have been formed.

I'm wondering, given the distance we all have on our experiences within our two formal learning communities, what are you actively making of those experiences now?

Musonda: I enrolled in our second class together immediately upon my release from prison, inspired by the happenings in our first class. Though it did not lend itself to the heightened environment of the Inside-Out class, I entered into it with a greater confidence than before. I felt comfortable around people across the gender spectrum and, though cisgender, I did not feel like "other." On a personal level, and especially considering my upbringing, this is a huge breakthrough, because I had not only learnt empathy but could also identify with the prejudices and stereotypes that have been attached to people that do not fit the norm. I believe that there is a 
continuing "performance of self" in what I am doing and pursuing, because I not only recognize others and their humanity but also recognize and appreciate my own. I have a view now on the possibilities of being free to live and love in our own truth—and not only to live our own truth, but also to empower others in their journey.

Lindsay: I agree with Mus; we definitely learned to recognize and value those shared pieces of ourselves - and that is a gift that extends far beyond our classrooms. Relatedly, I think one of the greatest takeaways from our time together (especially now as a graduate, able to apply our learnings beyond my academic studies) is the humbling awareness it has granted me—in that I recognize that I don't know far more than I do. I have a better understanding of the meaning of care, not only with regards to my own well-being, but for those who may be othered in a certain circle, as much as those who appear to be directly in line with its hegemony. As redundant as it may seem to state again, we do all have such individual narratives embedded within so many universal experiences; no matter where one lies on the spectrum, each story deserves the chance to be told and appreciated purely for its existence; we shouldn't have to earn the right to be heard. Regardless of someone's level of vulnerability or willingness to divulge themselves, they can still be valued simply as they are-which is not to say we are all faultless or needn't work to improve ourselves, but rather we can offer an act of care in accepting someone where they stand, rather than wrongfully vilifying them for a lack of questioning something they never knew they should. (Even in drafting this, I am conscious of my pronoun choice, frustrated by the limitations of English grammar; so I am purposely choosing to use the more inclusive "they" rather than the technically correct but wrongfully exclusive "his/her" in reference to a single subject.) Especially in today's climate, I consistently must remind myself to pause, to remember that the person with whom I may be in a fervent debate formed their beliefs from experiences I very well may not 
know. Anger turns to empathy, my own self-righteousness resigns, and I can remember to listen, to share when pertinent, and to take each opportunity to learn from those across from me in hopes of continuing the cycle. The way I carry myself (perform), the way I communicate, the way I care for my self and the selves around me - all have been directly influenced by these experiences, and I am surely better because of them.

Vicki: We're nearly at our time limit for this discussion, and our space limit for this essay—but we're seeing each other next week to finish this article, and we're committed to staying in connection even as our situations change, and change, and change. With your permission, I'm going to end this essay with some of the first reflective writing I did when we decided to work on this project together:

Why do we bring our individual selves into community together, performing care with each other in these contested spaces? Because we have, each of us differentially, but each of us in some way or other, experienced the violence that attends our experiences in universities and in prisons, in our families and in our communities, in the streets and in our cells and in our bedrooms. One thing we can do about that violence is co-create spaces in which we can voice our experiences, where we can edge toward the center from the margins, where we can collectively work to expand the center so that the center is the entirety of the place in which we are situated. One thing we can do is choose to relate to each other differently than most of us have been allowed to relate in these structured, surveilled, power-riven spaces, to meet each other where we are, to invite our whole selves onto the scene, and to experience what happens inside our minds and hearts and bodies when we do so. Together, we resist, and we become resistance. We can become antidote, however transitory. We can tell our stories, and our story. Until we reversed the steps we outsiders took to come inside on that first evening of our 
class and every time after that, we didn't stop. We still don't stop. We talk and we co-teach and we co-learn and we share our selves and our voices and our words like there's no tomorrow, because for so many of us and for so many reasons, there might not be. Even after we are made to leave, we don't stop. We just don't stop.

\section{works cited}

Butler, Judith. "Performative Acts and Gender Constitution: An Essay in Phenomenology and Feminist Theory." Theatre Journal, vol. 40, no. 4, 1988, pp. 519-31. JSTOR, doi:10.2307/3207893. Accessed 15 June 2018.

Folbre, Nancy. "Who Cares? A Feminist Critique of the Care Economy." Rosa Luxemburg Stiftung New York Office, 2014, www.rosalux-nyc.org/wpcontent/files mf/folbre whocares.pdf. Accessed 15 December 2018.

Freire, Paulo. Pedagogy of the Oppressed, 30th Anniversary Edition. Continuum, 2000.

Ghorashi, Halleh. "Bringing Polyphony One Step Further: Relational Narratives of Women from the Position of Difference.” Women's Studies International Forum, vol. 43, 2014, pp. 59-66. Science Direct, doi:10.1016/j.wsif.2013.07.019. Accessed 15 June 2018.

Hamington, Maurice. "A Performative Approach to Teaching Care Ethics: A Case Study." Feminist Teacher, vol. 23, no.1, 2012, pp. 31-49, JSTOR, jstor.org/stable/10.5406/femteacher.23.1.0031. Accessed 15 June 2018. 
hooks, bell. Teaching Community: A Pedagogy of Hope. Routledge, 2003.

----- . Teaching to Transgress: Education as the Practice of Freedom. Routledge, 1994.

Medina, José. Speaking from Elsewhere: A New Contextualist Perspective on Meaning, Identity, and Discursive Agency. SUNY Press, 2006.

Palmer, Parker. "Born Baffled: Musings on a Writing Life." Center for Courage \& Renewal, 18 August 2015, www.couragerenewal.org/born-baffled-musings-on-a-writing-life-parker-palmer/. Accessed 13 July 2018.

Reynolds, Candyce. Private conversation. 2008.

Willett, Cynthia, et al. "Feminist Perspectives on the Self." The Stanford Encyclopedia of Philosophy, Winter 2016 (Winter 2016 Edition), plato.stanford.edu/archives/win2016/entries/feminism-self/. Accessed 15 December 2018.

\section{NOTES}

\footnotetext{
${ }^{1}$ We understand ourselves to be full co-authors of this text, as we collaborated equitably in its production.

${ }^{2}$ Temple University's Inside-Out Prison Exchange Program supports faculty members to offer courses inside correctional facilities in which half of the students are incarcerated at the facility and half of the students enter the facility from the sponsoring college/university for integrated
} 
class sessions. For more information, see www.insideoutcenter.org.

${ }^{3}$ To receive the syllabus or other materials from the courses discussed here, contact Vicki Reitenauer, vicr@pdx.edu. ${ }^{4}$ See, for example, Nancy Folbre's "Who Cares? A Feminist Critique of the Care Economy," ${ }^{5}$ In our conversations about this project, we talked a lot about this issue. While Vicki does facilitate pronoun checks in her campus-based courses (and did in the memoir class Musonda and Lindsay took with her), she does not automatically engage this practice inside carceral settings, where the stakes in doing so are much different for persons incarcerated (particularly) in men's facilities. 